\title{
Tabanidae (Diptera) of the Amazon. XXII. First record of horse flies attacking golden tegu, Tupinambis teguixin Linnaeus 1758 (Reptilia: Squamata: Teiidae) \\ Tabanidae (Diptera) da Amazônia. XXII. Primeiro registro de mutucas atacando teiú-branco, Tupinambis teguixin Linnaeus 1758 (Reptilia: Squamata: Teiidae)
}

\author{
Inocêncio de Sousa Gorayeb!, Carlos Eduardo Costa de Campos ${ }^{\text {II }}$ \\ 'Museu Paraense Emílio Goeldi/MCTIC. Belém, Pará, Brasil \\ "Universidade Federal do Amapá. Macapá, Amapá, Brasil
}

\begin{abstract}
This is the first record of horse flies (Diachlorus curvipes and Tabanus occidentalis) were collected attacking and feeding on the blood of the golden tegu lizard (Tupinambis teguixin) at the Maracá-Jipióca Ecological Station, municipality of Amapá, Brazil.

Keywords: Insect. Horsefly. Lizard. Jacuraru. Hematophagy. Eastern Amazon.

Resumo: Este é o primeiro registro de tabanídeos (Diachlorus curvipes e Tabanus occidentalis) atacando e fazendo repasto sanguíneo no teiú-branco (Tupinambis teguixin) na Estação Ecológica Maracá-Jipióca, no município de Amapá, Brasil.
\end{abstract}

Palavras-chave: Insecta. Mutuca. Lagarto. Jacuraru. Hematofagia. Amazônia oriental.

GORAYEB, I. S. \& C. E. C. CAMPOS, 2018. Tabanidae (Diptera) of the Amazon. XXII. First record of horse flies attacking golden tegu, Tupinambis teguixin Linnaeus 1758 (Reptilia: Squamata: Teiidae). Boletim do Museu Paraense Emílio Goeldi. Ciências Naturais 13(1): 157-160. Autor para correspondência: Inocêncio de Sousa Gorayeb. Museu Paraense Emílio Goeldi/MCTIC. Coordenação de Zoologia. Entomologia. Av. Perimetral, 1901 - Terra Firme. Belém, PA, Brasil. CEP 66077-830 (gorayeb@museu-goeldi.br).

Recebido em 29/10/2017

Aprovado em 20/01/2018

Responsabilidade editorial: Fernando da Silva Carvalho Filho

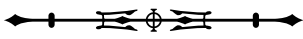




\section{INTRODUCTION}

Horseflies (Diptera: Tabanidae) are true flies ranging in size from 5 to $30 \mathrm{~mm}$, with generally robust body and large eyes. Adult tabanids are found in almost all habitats, such as salt lakes, beaches, deserts, forests, and mountains up to the snow line in the Andes. Some species prefer more open habitats such as those created by agriculture (Fairchild, 1981).

Adult of both sexes feed on nectar and sugary substances (honeydew) produced by sap-sucking insects, but adult females feed on blood after mating. Therefore, only the adult females can transmit diseases agents of that accumulate in the mouthparts, salivary glands, and tarsi (Krinsky, 1976).

The adult hematophagous females attack mainly large mammals such as sloths, tapirs, domestic and wild ungulates, and humans (Fairchild, 1981), but there are also records for birds (Limeira-de-Oliveira et al., 2002), turtles, Squamata (snakes and lizards), and Crocodilians (Medem, 1981; Henriques et al., 2000; Ferreira et al., 2002).

Most records of horsefly species attacking cold-blooded animals are for crocodilians and chelonians, and there are few records for Squamata. Surcouf (1923) recorded Tabanus guyanoe (Surcouf, 1922) attacking a monitor lizard [Varanus griseus (Daudin, 1803)] in the Sahara desert in Algeria, and Gouteux et al. (1989) recorded Chrysops silacea Austen, 1907 and C. dimidiata Wulp, 1885 attacking varanid lizards in the Congo. Philip (1976) recorded the attack of horseflies on snakes in the genus Boa in Colombia and Panama, and Philip (1986) recorded four horse fly species attacking anaconda [Eunectes murinus (Linnaeus, 1758)] in Peru. Philip (1983) recorded Stenotabanus stigma (Fabricius, 1805) attacking iguanas on the Galapagos Islands. Ferreira et al. (2002) verified the diurnal activity and seasonality of captured tabanids using two species of cold-blooded hosts, the common caiman (Caiman crocodilus Linnaeus, 1758) and anaconda; in his study four species were recorded: Stenotabanus cretatus Fairchild, 1961, Stenotabanus bequaerti Rafael, Fairchild \& Gorayeb, 1982, Phaeotabanus nigriflavus (Krober, 1930), and Tabanus occidentalis Linnaeus, 1758, all attacking both hosts.
This research note presents the first record of tabanid attack on the golden tegu, Tupinambis teguixin Linnaeus 1758 (Reptilia: Squamata: Teiidae).

\section{METHODS}

\section{STUDY AREA}

This study was carried out at the Maracá-Jipióca Ecological Station (ESEC), which is a coastal island in Amapá municipality, with an area of 72,000 hectars. ESEC is formed by two islands, North Maracá Island and South Maracá Island (206' 15.89” N; 50²8' 36.77” W), divided by a channel known locally as 'Inferno stream', and Jipióca Island. The relief is low and confers little difference on the landscape, with vegetation such as floodplain, mangrove, dunes, forest, and few raised areas locally called 'tesos' (Vergara \& Stephano, 2010).

Observations and collections were carried out in July and October of 2016, in the morning, in an area behind the headquarters of the Chico Mendes Institute of Biodiversity Conservation (2॰ 5' 49.5" N; 50²9' 53.7" W).

Photographs were made with a Canon EOS Rebel T6 DSLR digital camera. Horse fly specimens are deposited in the Entomological Collection of the Institute of Scientific and Technological Research (IEPA) in Amapá, Macapá, Brazil.

\section{RESULTS}

Initially, a golden tegu lizard was observed on North Maracá Island being attacked by two species of horse flies on 16 July 2016, during the morning from 10:00 to 11:00 $\mathrm{h}$.

On 11 October 2016, a golden tegu was captured, immobilized, and left on the ground in low vegetation from 13:00 to 14:00 h. During this period, 18 individual horse flies Diachlorus curvipes (Fabricius, 1805) and two T. occidentalis were observed on the lizard's head and back, biting in the membranous areas between scales near the mouth and eyes (Figures 1-3).

After the horse flies'attack, several drops of blood could be seen at the bite location (Figure 3). 


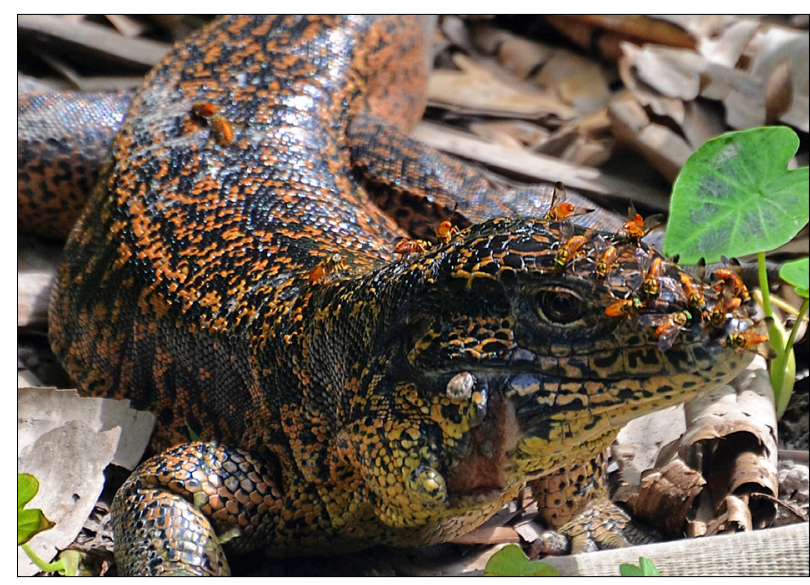

Figure 1. Golden tegu (Tupinambis teguixin Linnaeus, 1758) with horsefly Diachlorus curvipes (Fabricius, 1805) on the head and back, taking a blood meal. Maracá-Jipióca Ecological Station, Amapá, Macapá. Photo: Carlos Eduardo Costa de Campos.

The golden tegu did not scratch the bites nor show any reaction to the attack of the tabanids.

\section{DISCUSSION}

The two horse fly species attacking the golden tegu are common and widely distributed. T. occidentalis occurs from Mexico to Argentina, and D. curvipes is distributed from Costa Rica to northern South America (Coscarón \& Papavero, 2009).

T. occidentalis is one of the most common and abundant species in the Amazon region, occurring in open and forested areas (Gorayeb, 1985, 1993, 1999, 2000), as a generalist species that attacks various groups of animals including humans. This is first report of the species attacking the golden tegu.

In studies conducted by Gorayeb (1985, 1993, 1999 , 2000) in the eastern Amazon, D. curvipes was among the most abundant species, however there is little information on the biology of the species.

Several species of horse flies are feed on warm and cold-blooded animals, as is the case of T. occidentalis. However, some species are restricted to a few hosts. $D$. curvipes has already been recorded attacking humans, horses, oxen, and caimans (I. S. Gorayeb, personal observation),

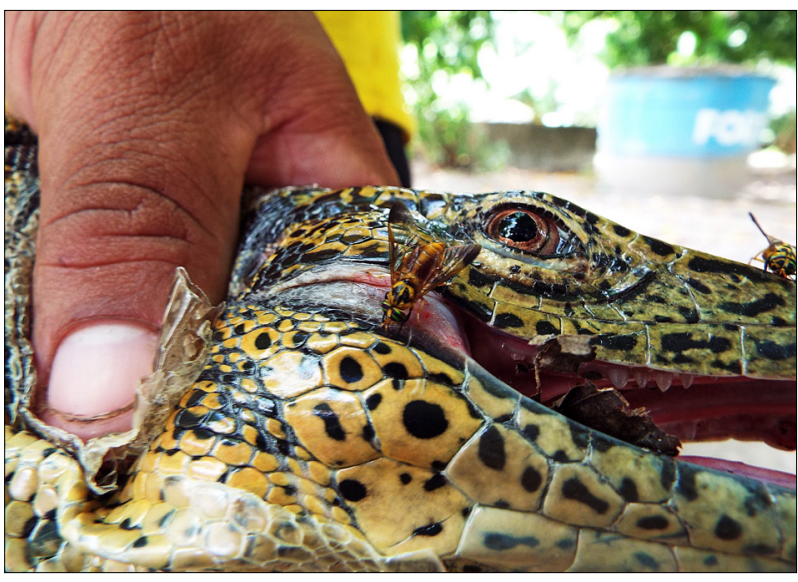

Figure 2. Golden tegu (Tupinambis teguixin Linnaeus, 1758) with Diachlorus curvipes (Fabricius, 1805), biting between the scales on the head and on the mouth membrane. Maracá-Jipióca Ecological Station, Amapá, Macapá. Photo: Carlos Eduardo Costa de Campos.

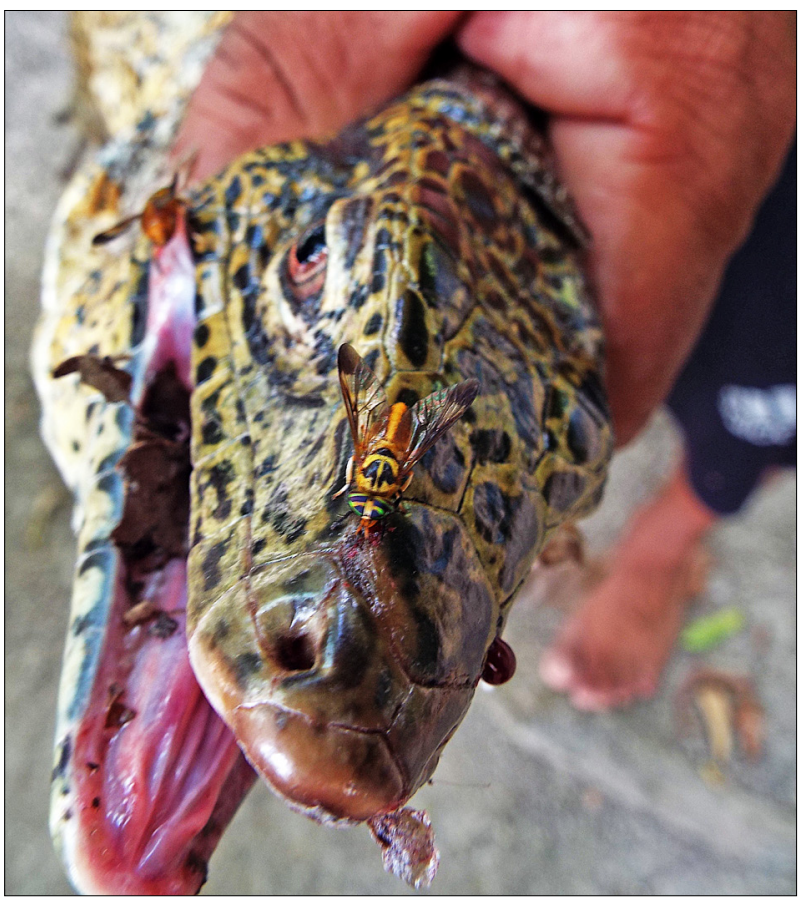

Figure 3. Golden tegu (Tupinambis teguixin Linnaeus, 1758) with Diachlorus curvipes (Fabricius, 1805) on the head, with a drop of blood visualable at the bite. Maracá-Jipióca Ecological Station, Amapá, Macapá. Photo: Carlos Eduardo Costa de Campos.

but it is unable to feed on the blood of some of these hosts. According to Gorayeb (1985), D. curvipes individuals were unable to feed on horses used as baits, although they were

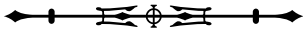


attracted to and rested on the animals' legs. The horse fly individuals in this report fed on the golden tegu lizard. This tabanid species, despite visiting both warm and cold-blooded animals, may be specialized to feeding on lizards.

The distribution of $D$. curvipes includes Costa Rica, Panama, Colombia, Venezuela, Guiana, Suriname, French Guiana, eastern Peru, Bolivia, and Brazil (Amapá, Pará, Roraima, Rondônia, Mato Grosso, Minas Gerais), and Trinidade (Coscarón \& Papavero, 2009). This distribution coincides with that of the golden tegu, which suggests a consistent host relation in evolutionary terms.

\section{CONCLUSION}

This is the first record of $D$. curvipes and $T$. occidentalis attacking the golden tegu lizard (Tupinambis teguixin).

Unlike T. occidentalis, which feeds on both warmblooded and cold-blooded animals, D. curvipes is possibly associated with cold-blooded animals or even large lizards. Although $D$. curvipes has already been reported attacking caimans, horses, and humans, it apparently can not feed on mammalian blood.

\section{REFERENCES}

COSCARÓN, S. \& N. PAPAVERO, 2009. Catalogue of Neotropical Diptera. Tabanidae. Neotropical Diptera 16: 1-199.

FAIRCHILD, G. B., 1981. Tabanidae. In: S. H. HURLBERT, G. RODRIGUEZ \& N. D. SANTOS (Ed.): Aquatic biota of tropical South America: Arthropoda: 290-301. San Diego State University, San Diego.

FERREIRA, R. L. M., A. L. HENRIQUES \& J. A. RAFAEL, 2002. Activity of tabanids (Insecta: Diptera: Tabanidae) attacking the reptiles Caiman crocodilus (Alligatoridae) and Eunectes murinus (Linn.) (Boidae) in the Central Amazon, Brazil. Memórias do Instituto Oswaldo Cruz 97(1): 133-136. DOI: <http://dx.doi.org/10.1590/ S0074-02762002000100024>.

GORAYEB, I. S., 1985. Tabanidae (Diptera) da Amazônia oriental: sazonalidade, ataque e estratificação arbórea: 1-205. Tese (Doutorado) - Instituto Nacional de Pesquisas da Amazônia, Manaus.

GORAYEB, I. S., 1993. Tabanidae (Diptera) da Amazônia. XI Sazonalidade das espécies da Amazônia oriental e correlação com fatores climáticos. Boletim do Museu Paraense Emílio Goeldi, Série Zoologia 9(2): 241-281.
GORAYEB, I. S., 1999. Tabanidae (Diptera) of the Amazon. XIV. Vertical stratification in an eastern Amazonian forest. Memoirs on Entomology International 14: 367-386.

GORAYEB, I. S., 2000. Tabanidae (Diptera) da Amazônia. XVI. Atividade diurna de hematofagia de espécies da Amazônia oriental, em áreas de mata e pastagens correlacionada com fatores climáticos. Boletim do Museu Paraense Emílio Goeldi, Série Zoologia 16(1): 23-63.

GOUTEUX, J. P., F. NOIREAU \& C. STAAK, 1989. The host preferences of Chrysops silacea and C. dimidiata (Diptera: Tabanidae) in an endemic area of Loa loa in the Congo. Annals of Tropical Medicine and Parasitology 83(2): 167-172.

HENRIQUES, A. L., R. L. M. FERREIRA, J. F. VIDAL \& J. A. RAFAEL, 2000. Betrequia ocellata Oldroyd (Diptera, Tabanidae, Rhinomyzini) blood feeding on Caiman crocodilus (Linnaeus) (Crocodylia, Alligatoridae) in Manaus, Brazil. Revista Brasileira de Zoologia 17(3): 609-613. DOI: <http://dx.doi.org/10.1590/ S0101-81752000000300007>.

KRINSKY, W. L., 1976. Animal disease agents transmitted by horse flies and deer flies (Diptera: Tabanidae). Journal of Medical Entomology 13(3): 225-275.

LIMEIRA-DE-OLIVEIRA, F., J. A. RAFAEL \&A. L. HENRIQUES, 2002. Phorcotabanus cinereus (Wiedemann, 1821) (Diptera:Tabanidae) an Ornithophilic Species of Tabanid in Central Amazon, Brasil. Memórias do Instituto Oswaldo Cruz 97(6): 839-842. DOI: <http://dx.doi.org/10.1590/S0074-02762002000600015>.

MEDEM, F., 1981. Horse flies (Diptera: Tabanidae) as ectoparasites on caimans (Crocodylia: Alligatoridae) in eastern Colombia. Cespedesia 10(37-38): 123-191.

PHILIP, C. B., 1976. Horse-flies, too, take some victims in cold-blood, as on Galapagos Isles. Pan-Pacific Entomologist 52: 84-88.

PHILIP, C. B., 1983. A unique, divergent developmental dependence of a Galapagos tabanid (Diptera, Tabanidae). Wasmann Journal of Biology 41: 47-49.

PHILIP, C. B., 1986. A collection of four species of tabanid flies taken from an anaconda snake in Peru in May, 1984. The Pan-Pacific Entomologist 62(1): 23.

SURCOUF, J., 1923. Diptères nouveaux ou peu connus. Annales de Societe Entomologique de France 41: 237-244.

VERGARA, M. \& A. STEPHANO, 2013. Estudo populacional de Panthera onca (Carnivora, Felidae) na Estação Ecológica de MaracáJipioca, Amapá, Brasil. In: L. T. L. SIMONIAN, A. J. S. COSTA \& E. R. BAPTISTA (Org.): Escudo Guianês: biodiversidade, conservação dos recursos naturais e cultura: 67-84. NAEA/GSF, Belém. 